\title{
Short communication: Associations between nonesterified fatty acids, $\beta$-hydroxybutyrate, and glucose in periparturient dairy goats
}

\author{
F. Zamuner, ${ }^{1 *}$ ๑ K. DiGiacomo, ${ }^{1} \odot$ A. W. N. Cameron, ${ }^{2}$ and B. J. Leury ${ }^{1} \odot$ \\ ${ }^{1}$ Faculty of Veterinary and Agricultural Sciences, University of Melbourne, Parkville, Victoria 3010, Australia \\ ${ }^{2}$ Meredith Dairy Pty Ltd., 106 Cameron Rd., Meredith, Victoria 3333, Australia
}

\begin{abstract}
The objective of the present study was to use longitudinal data to examine the relationships between blood concentrations of nonesterified fatty acids (NEFA), $\beta$-hydroxybutyrate (BHB), and glucose during the transition period in dairy goats. Weekly blood samples were collected from Saanen goats from a commercial herd in Australia [1-7 yr; body weight $70 \pm 16.0 \mathrm{~kg}$; body condition score $2.5 \pm 0.3$; and daily milk yield $2.4 \pm 0.73 \mathrm{~L} / \mathrm{d}$; all mean \pm standard deviation $(\mathrm{SD})]$. The weekly prevalence of goats above hyperketonemic levels (BHB $\geq 0.8 \mathrm{mmol} / \mathrm{L}$ ) was approximately 6 times greater postpartum than antepartum. As well, of the 935 goats sampled antepartum, $50(5 \%)$ had at least 1 hyperketonemic event, and $823(88 \%)$ had at least 1 event of NEFA above the threshold $(\geq 0.3 \mathrm{mmol} / \mathrm{L})$. Of 847 goats tested postpartum, $258(30 \%)$ had at least 1 hyperketonemic event, and 690 goats $(81 \%)$ had at least 1 event of NEFA above the threshold ( $\geq 0.7 \mathrm{mmol} / \mathrm{L})$. Substantial variation was found when analyzing the mean days of maximum NEFA and maximum BHB concentrations antepartum $(-11 \pm 6.6$ and $-14 \pm 7.2$ $\mathrm{d}$, respectively, mean $\pm \mathrm{SD})$ and postpartum $(14 \pm 6.6$ and $9 \pm 6.8 \mathrm{~d}$, respectively, mean $\pm \mathrm{SD})$. We observed moderate to strong relationships between NEFA and BHB concentrations $(\mathrm{r}=0.66)$ and between NEFA and glucose concentrations $(\mathrm{r}=-0.46)$ throughout the transition period. Our results suggested that 3 to 16 $\mathrm{d}$ in milk is the best sampling window for monitoring hyperketonemia in dairy goats, and that results from simultaneous BHB and glucose tests provide an improved indication of the fat mobilization and energy status of the herd when measured close to this timeframe.
\end{abstract}

Key words: transition period, energy metabolites, correlation, prevalence

Received June 26, 2019.

Accepted February 11, 2020.

*Corresponding author: fzamuner@student.unimelb.edu.au

\section{Short Communication}

The period from 3 wk before to 3 wk after parturition, defined as the transition period in dairy animals (Grummer, 1995), is characterized by depressed feed intake and increased nutrient requirements (for fetal development and milk production), often resulting in negative energy balance (NEB; Wankhade et al., 2017). Intensified mobilization of body fat reserves and elevation of circulating nonesterified fatty acids (NEFA) and BHB is an adaptive response to NEB to supply peripheral tissues with alternative energy sources, sparing glucose for fetal development and milk synthesis (Baumgard et al., 2017). However, a considerable amount of work has linked elevated blood levels of NEFA and BHB to increased incidence of NEB-related diseases in transitioning dairy cows (McArt et al., 2013; Overton et al., 2017).

Over the last $20 \mathrm{yr}, \mathrm{NEFA}$ and BHB have become the accepted biomarkers of excessive NEB or maladaptation of energy metabolism to lactation in cows (Overton et al., 2017), and antepartum (NEFA $\geq 0.3-0.5$ and $\mathrm{BHB} \geq 0.6-0.8 \mathrm{mmol} / \mathrm{L}$ ) and postpartum (NEFA $\geq 0.7-1.0$ and $\mathrm{BHB} \geq 1.0-1.4 \mathrm{mmol} / \mathrm{L}$ ) thresholds have been established to predict the risk of NEB-related diseases and milk loss in transition dairy cows (Overton et al., 2017; Wankhade et al., 2017). Similarly, studies in dairy goats have demonstrated that plasma $\mathrm{BHB} \geq 0.8$ $\mathrm{mmol} / \mathrm{L}$ is associated with subclinical ketosis, and $\mathrm{BHB}$ $>1.6 \mathrm{mmol} / \mathrm{L}$ is associated with clinical ketosis (Albay et al., 2014; Doré et al., 2015; Marutsova and Binev, 2017). However, specific NEFA reference values have not been established for goats (Radin et al., 2015).

Although NEFA has been proposed as a better predictor of NEB status and disease risk than BHB and glucose (McArt et al., 2013), testing for NEFA is expensive and practically challenging. In contrast, several point-of-care meters have been validated for measurement of blood BHB and glucose concentrations in cows, ewes, and does (Pichler et al., 2014; Overton et al., 2017; Panousis et al., 2018). This inexpensive method provides producers, practitioners, and investigators 
with an important diagnostic and screening tool. However, the determination of BHB and glucose cut-points associated with negative outcomes in dairy goats would require large epidemiological studies in different herds. A perusal of the literature revealed only 1 cohort study on optimal BHB thresholds for predicting the risk of prepartum hyperketonemia in dairy goats (Doré et al., 2015), and no similar studies have been reported in lactating goats.

The aims of this study were (1) to use longitudinal data to estimate the ante- and postpartum prevalence of goats with BHB levels above thresholds and the prevalence of goats with elevated NEFA (based on dairy cattle thresholds); and (2) to examine the temporal relationships between circulating concentrations of NEFA, BHB, and glucose in periparturient dairy goats from a commercial herd in Australia.

All experimental procedures were approved by the Faculty of Veterinary and Agricultural Sciences Animal Ethics and Welfare Committee of the University of Melbourne, Australia (No. 1613846.1).

This experiment was conducted at Meredith Dairy commercial farm (Meredith, Australia, 37 50'S; $144^{\circ} 04^{\prime} \mathrm{E}$ ) over 4 consecutive kidding seasons, from June 2016 to March 2017, in parallel with a production trial using 1,000 Saanen goats $[\sim 250$ different goats each kidding season; $1-7 \mathrm{yr} ; 69 \pm 14.0 \mathrm{~kg} \mathrm{BW}$; mean \pm standard deviation (SD)]. Further details on animals and management are available in Zamuner et al. (2020). In brief, the enrolled goats were kept with their contemporary group ( $\sim 600$ goats $)$ in a collective pen and began to receive the fresh-goat TMR 1 mo before the expected kidding date. Goats were fed ad libitum once per day at approximately $0700 \mathrm{~h}$. The approximate nutrient composition (DM basis) of the diet was as follows: $32 \% \mathrm{NDF}, 16 \% \mathrm{CP}, 10 \mathrm{MJ}$ of ME, $18 \mathrm{~g}$ of $\mathrm{Ca}$, and $9.0 \mathrm{~g}$ of $\mathrm{P} / \mathrm{kg}$ of $\mathrm{DM}$.

Blood samples were collected from all does $(\sim 250$ each kidding season) on the same day at approximately $1000 \mathrm{~h}$, always after the morning milking. On the day of blood sampling, feed was withheld until after blood collection. Goats were sampled in random order, and the average interval between the first and last animal sampled was $166 \pm 30 \mathrm{~min}( \pm \mathrm{SD})$. Blood collection was carried out once weekly for 7 consecutive weeks, starting at wk -3 relative to expected kidding date of each kidding season. The actual day of sampling (in relation to delivery) was determined after birth by sampling date - kidding date, and data were segmented in weekly intervals (i.e., $-21 \pm 3 \mathrm{~d}=\mathrm{wk}-3 ;-14 \pm 3 \mathrm{~d}$ $=\mathrm{wk}-2$; and so forth).

Blood was harvested via jugular venipuncture into 10-mL lithium heparin (170 IU) evacuated tubes (BD
Vacutainer, Plymouth, UK) and immediately placed on ice until plasma separation. The whole-blood concentration of BHB was measured using a handheld meter (FreeStyle Optium Precision Neo; Abbott Diabetes Care Ltd., Witney, UK) before centrifugation $(1,250 \times$ $g, 12 \mathrm{~min}, 4^{\circ} \mathrm{C}$ ). Isolated plasma was stored at $-20^{\circ} \mathrm{C}$ until analysis. Plasma NEFA and glucose concentrations were determined spectrophotometrically using commercial kits: NEFA-C ACS-ACOD Method (Wako Pure Chemical Industries Ltd., Osaka, Japan), modified as per the methods of Johnson and Peters (1993); and Infinity Glucose Oxidase Liquid (Thermo-Scientific, Waltham, MA).

Statistical computations were performed using Minitab software (version 18.1; Minitab Inc., State College, PA). Plasma concentrations of NEFA, BHB and glucose were screened for normality by calculating kurtosis and skewness, and by visual assessment of standardized residuals distribution. Concentrations of NEFA and BHB were log-transformed to achieve normality. Data for log-transformed NEFA, log-transformed BHB, and glucose concentrations from d -24 to 24 were subjected to repeated-measures ANOVA using a mixed effects model (REML and 2-sided 95\% CI) in Minitab. The fixed effect was day of sampling, and the random effect was goat nested within kidding season to account for variations between kidding seasons. Fixed effects of parity number and litter size, as well as the covariant effects of time of bleeding, BW, and BCS, were tested in all models and retained when significant $(P<0.05)$. Results for logged NEFA and logged BHB were backtransformed for graphic presentation.

Spearman $\rho$ correlations were used to examine the relationships between weekly concentrations of NEFA, $\mathrm{BHB}$, and glucose. A multiple linear regression (2-sided, $95 \% \mathrm{CI}$ ) was used to evaluate the confidence in estimating logged NEFA using logged BHB and glucose concentrations as continuous predictors.

Days of maximum NEFA and BHB concentrations were determined for each goat in the data set before log-transformation and statistical analysis. We used the following cutoffs: $\geq 0.8 \mathrm{mmol} / \mathrm{L}$ and $>1.6 \mathrm{mmol} / \mathrm{L}$ for elevated BHB; and $\geq 0.3 \mathrm{mmol} / \mathrm{L}$ antepartum and $\geq 0.70 \mathrm{mmol} / \mathrm{L}$ postpartum for elevated NEFA (McArt et al., 2013). The antepartum calculations included data observations from $\mathrm{d}-24$ to -1 , and the postpartum calculations included data observations from d 0 to 24. Statistical significance was declared at $P<0.05$. Data are presented as mean $(95 \%$ CI $)$ unless declared otherwise.

Of the 1,000 animals enrolled, 60 were excluded from the experiment due to abortion, death, or kidding delay, for a total population of 940 . The final number of 


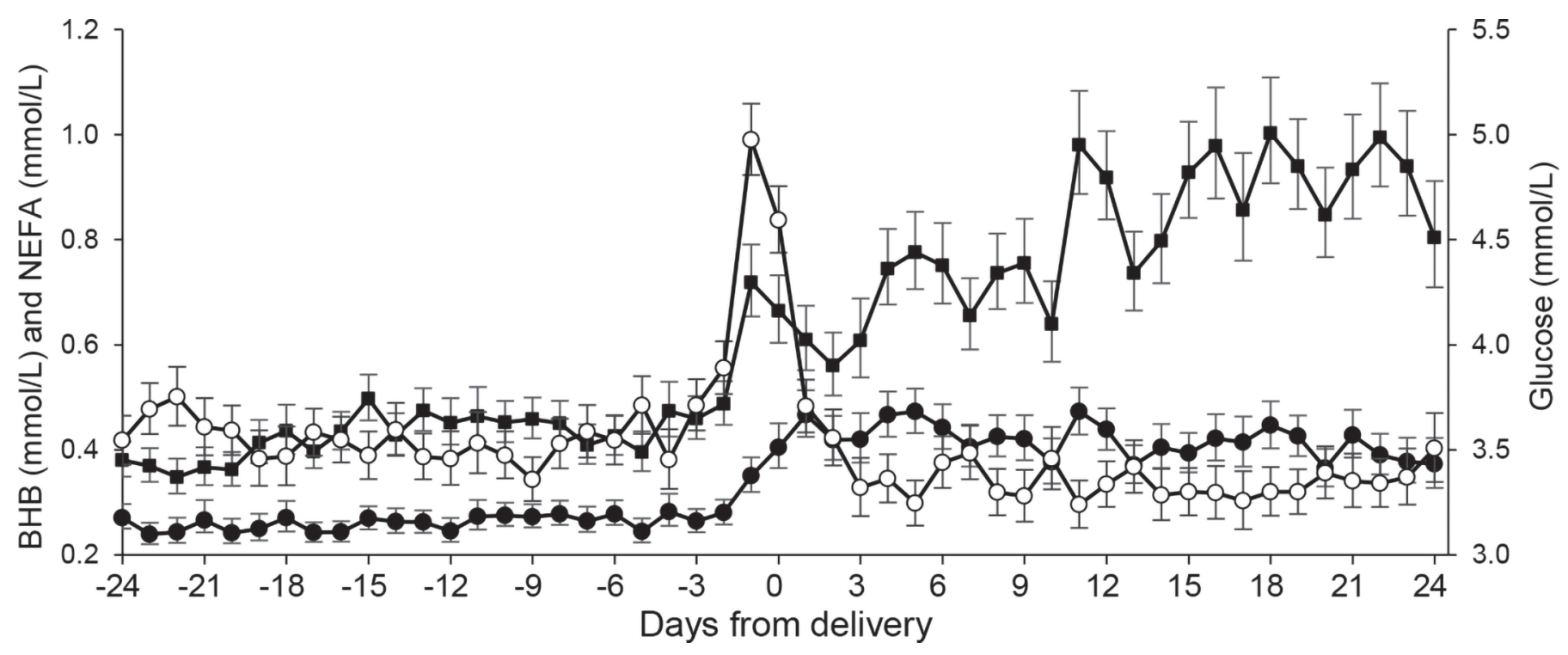

Figure 1. Daily plasma concentrations $(\mathrm{mmol} / \mathrm{L})$ of BHB $(\bullet)$, nonesterified fatty acids (NEFA; $\mathbf{\square})$, and glucose $(\bigcirc)$ in periparturient dairy goats sampled from -24 to 24 d relative to delivery; error bars represent $95 \%$ CI. Goats were sampled weekly and grouped by days from delivery based on their kidding dates (average number of samples collected at any given day between $\mathrm{d}-24$ and 24 was 118 ; range 68 to 156).

goats commencing the experiment were subdivided as follows: by season of kidding (March $=237$, June $=$ 242 , September $=222$, and November $=239)$; by parity number $(1=319,2=244,3=237,4=85,5=38$, and $6=17$ ); and by litter size ( single $=330$, twins $=$ 516 , and triplets $=94$ ). The average number of samples collected at any given day between d -24 to 24 was 118 (range 68 to 156). The total number of goats tested each week is presented in Table 1 . The average daily milk yield in the first month was $2.4 \pm 0.73 \mathrm{~L} / \mathrm{d}$ (mean $\pm \mathrm{SD})$.

To our knowledge, this is the first report using longitudinal data from a commercial herd to estimate the weekly prevalence of goats above critical levels of
NEFA and BHB during the transition period. Figure 1 describes daily variations of NEFA, BHB, and glucose from d 24 prepartum to d 24 postpartum. Previous studies in periparturient dairy goats have reported a similar increase in NEFA and BHB concentrations postpartum (Magistrelli and Rosi, 2014; Radin et al., 2015). However, these studies did not report the proportion of goats showing elevated plasma NEFA and BHB concentrations.

The present data showed a greater proportion of goats having BHB and NEFA concentrations above critical levels postpartum compared with antepartum (Table 1). Of the 935 goats tested antepartum (3,011 sampling events), the number of goats with at least 1 event was

Table 1. Weekly prevalence of goats above critical levels for nonesterified fatty acids (NEFA) and BHB, and weekly correlations between plasma concentrations (mmol/L) of NEFA, BHB, and glucose in Australian commercial dairy goats

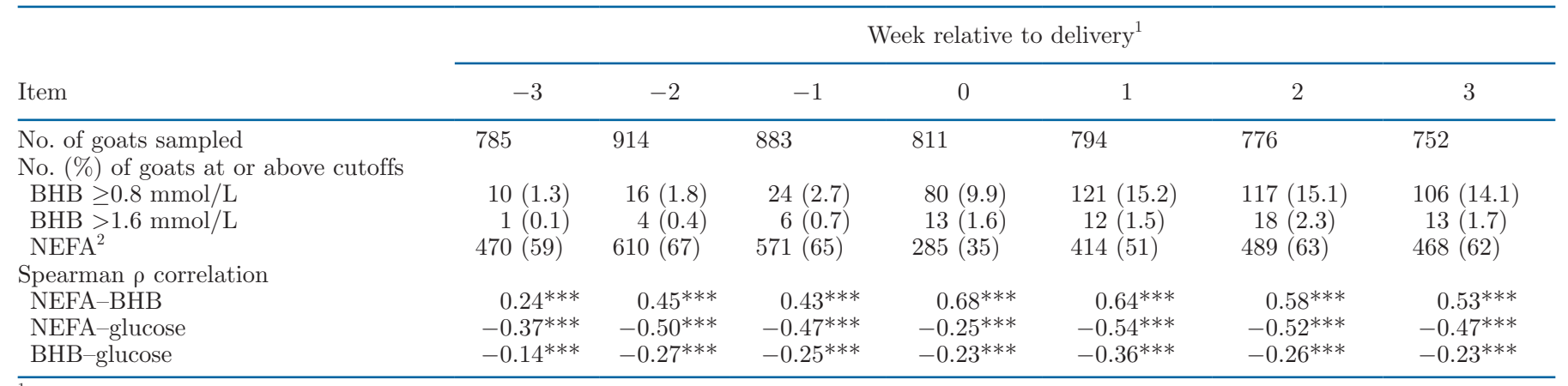

${ }^{1} \mathrm{wk}-3=\mathrm{d}-21 \pm 3 ;$ wk $3=\mathrm{d} 21 \pm 3$.

${ }^{2}$ Cutoffs for elevated NEFA concentration in dairy cows; NEFA $\geq 0.3 \mathrm{mmol} / \mathrm{L}$ antepartum (wk -3 to -1 ) and $\geq 0.7 \mathrm{mmol} / \mathrm{L}$ postpartum (wk 0 to 3 ; McArt et al., 2013).

$* * * P<0.001$. 
as follows: $\mathrm{BHB} \geq 0.8 \mathrm{mmol} / \mathrm{L}=50(5 \%)$;EFA $\geq 0.3$ $\mathrm{mmol} / \mathrm{L}=823(88 \%)$. From the 847 goats tested postpartum (2,767 sampling events), the number of goats with at least 1 event was as follows: $\mathrm{BHB} \geq 0.8 \mathrm{mmol} / \mathrm{L}$ $=258$ (30\%); NEFA $\geq 0.7 \mathrm{mmol} / \mathrm{L}=690$ (81\%). Ospina et al. (2010) studied more than 2,700 cows in 100 freestall dairies in the United States and reported that $34 \%$ of cows had NEFA $\geq 0.3 \mathrm{mmol} / \mathrm{L}$ (d -14 to -3 ) and $32 \%$ of cows had NEFA $\geq 0.7 \mathrm{mmol} / \mathrm{L}$ ( 3 to 14 DIM). Ospina et al. (2010) also reported that cows with values above such NEFA thresholds were twice as likely to be culled within 30 DIM. Comparatively, in the present study, the prevalence of goats with elevated NEFA was $77 \%$ antepartum and $64 \%$ postpartum (for the same thresholds and sampling period), whereas only $2 \%$ of the herd was culled within 30 DIM, suggesting that the NEFA threshold established for cows might not be predictive of performance in dairy goats.

Ketosis is one of the most common diseases affecting does and ewes regardless of farming purpose (i.e., dairy, meat, or wool/hair production; Rook, 2000). Contrary to the extensive information available on lactational ketosis in dairy cattle (McArt et al., 2012; Suthar et al., 2013), data on hyperketonemia in dairy goats are focused mainly on pregnancy ketosis (Albay et al., 2014; Doré et al., 2015; Vasava et al., 2016) and, to a lesser extent, on lactational ketosis (Yadav et al., 2015; Marutsova and Binev, 2017). Nevertheless, dairy goats with high genetic merit for milk production are prone to intense and prolonged NEB in early lactation (Smith and Sherman, 2009), emphasizing the importance of monitoring the energy status of dairy herds both antepartum and postpartum.

In the present study, the weekly prevalence of goats above hyperketonemic levels (BHB $\geq 0.8 \mathrm{mmol} / \mathrm{L}$ ) was approximately 6 times greater postpartum than antepartum (Table 1). Several authors have suggested that the best sampling window for early detection of hyperketonemia in dairy cows is between 2 to 3 and 14 to 16 DIM (McArt et al., 2012; Ospina et al., 2013; Suthar et al., 2013). In the present study, 258 goats (30\%) had at least 1 hyperketonemic episode from 0 to 24 DIM. Of those, 130 goats $(50 \%)$ had their first hyperketonemic episode between 3 and 16 DIM, indicating that the same sampling window might also be suitable for the observation of hyperketonemia in dairy goats.

To better understand the relationship between NEFA and $\mathrm{BHB}$, we examined the distribution of the day of maximum NEFA and day of maximum BHB (Table 2 ). Notably, the mean and median days of maximum BHB concentrations occurred earlier than the mean and median days of maximum NEFA concentrations. However, the large degree of variation in the days of peak BHB and NEFA concentrations prevented accu-

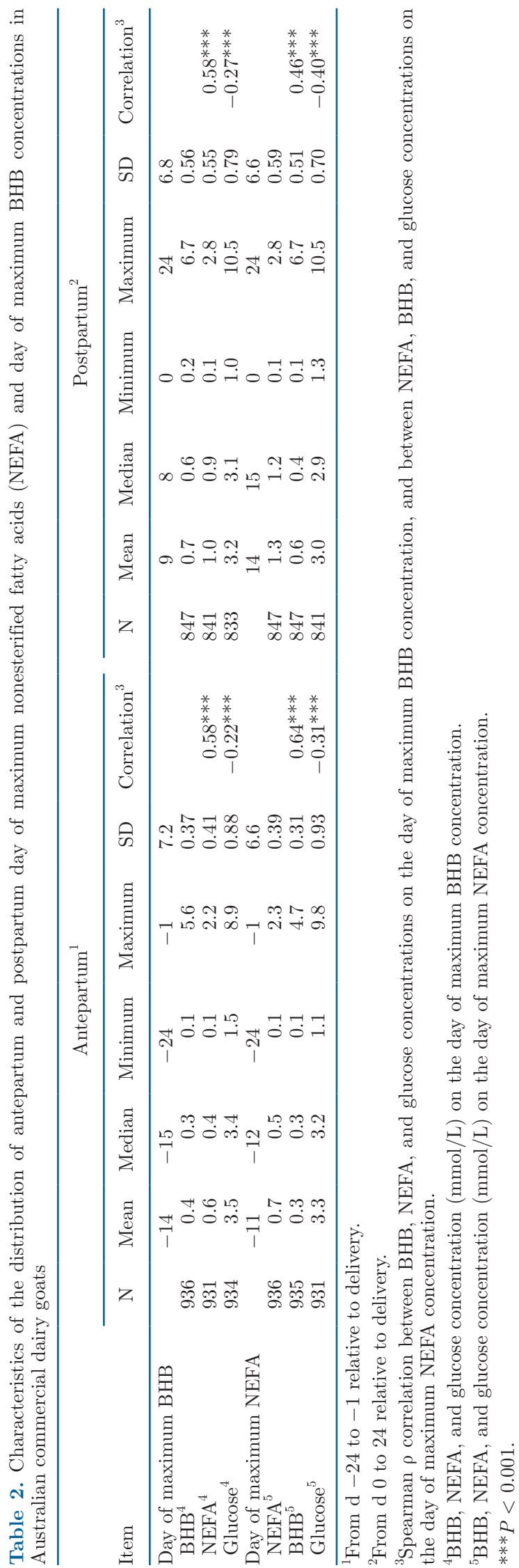


rate interpretation of data distribution. Neither parity nor litter size significantly affected the mean day of peak concentrations of NEFA and BHB.

We found substantial variation when we analyzed the mean $( \pm \mathrm{SD})$ day of maximum NEFA and BHB concentrations $(\mathrm{BHB}=-14 \pm 7.2$ and $9 \pm 6.8 \mathrm{~d}$, NEFA $=-11 \pm 6.6$ and $14 \pm 6.6 \mathrm{~d}$, ante- and postpartum, respectively). Further analysis showed that for most goats, the day of maximum BHB was the same as the day of maximum NEFA: antepartum $=439$ goats $(47 \%)$; postpartum $=390$ goats $(46 \%)$. Interestingly, the day of maximum BHB occurred before the day of maximum NEFA in most of the remaining goats: antepartum $=372$ goats $(40 \%)$, postpartum $=373$ goats (44\%). Harmeyer and Schlumbohm (2006) have demonstrated that pregnant ewes have a reduced ability to use BHB. Additionally, Reynolds et al. (2003) observed that variations in the liver release of $\mathrm{BHB}$ could be attributed not only to changes in the liver removal of NEFA but also to diet-induced changes in circulating levels of other ketogenic precursors, such as butyrate and acetoacetate. Therefore, the relatively earlier peak of BHB could be related in part to BHB overproduction in times of impaired use, and to individual differences in hepatic energy metabolism, rather than solely due to increased removal of NEFA by the liver. Nevertheless, the reasons for the present findings remain speculative.

Despite a considerable body of evidence linking elevated NEFA and BHB to negative downstream outcomes in dairy animals (Overton et al., 2017), recent studies reported either weak $(r=0.20$; McCarthy et al., 2015) or absent (Pilotto et al., 2016) correlations between NEFA and BHB in transitioning dairy cows. In contrast, we observed a moderate to strong relationship between concentrations of NEFA and BHB ( $\mathrm{r}=$ $0.66)$ and NEFA and glucose $(\mathrm{r}=-0.46)$ throughout the transition period $(5,686$ simultaneous sampling events from $\mathrm{d}-24$ to 24 ), and on the NEFA and BHB days of peak concentration (Table 2). Similarly, moderate relationships between NEFA and BHB have been reported in healthy does in the last week of pregnancy $(\mathrm{r}=0.45)$ and in periparturient dairy ewes $(\mathrm{r}=0.41$; Karagiannis et al., 2014; Radin et al., 2015), suggesting a stronger association between BHB and NEFA in small ruminants than in dairy cows. Although the reason for the interspecies differences is unclear, recent studies have reported relevant distinctions in intermediary metabolism and mammary lipogenesis between cows and goats (Bernard et al., 2017; Fougère et al., 2018), which could explain the different correlation strengths between BHB and NEFA reported in cows and goats.

Plasma NEFA concentration reflects the magnitude of fat mobilization from body reserves (LeBlanc, 2010). The moderately strong correlations observed between NEFA and BHB, and between NEFA and glucose, puts forward the idea that combined results from BHB and glucose tests could be a potential alternative to laboratory analysis of NEFA concentrations in estimating the rate of fat metabolism in dairy goats. Nonetheless, in the present study, variations in plasma BHB and glucose explained approximately $47 \%$ of the observed variations in NEFA concentrations from 4 to 17 DIM (Table 3). Taken together, results for weekly correlations (Table 1) and regression analysis (Table 3) clearly demonstrate that the strength of the association between the selected metabolites varies with time, and that such associations are stronger during the 2 first weeks of lactation. These findings suggest that simultaneous BHB and glucose tests would provide a more accurate estimation of the actual nutritional status of dairy goats when measured within 4 to 17 DIM.

Our results showed a greater prevalence of goats above the cutoff for elevated BHB and NEFA after kidding, demonstrating that in dairy goats, as with

Table 3. Coefficients of determination $\left(\mathrm{R}^{2}\right)^{1}$ and estimates (95\% CI) for multiple linear regression model based on continuous BHB ${ }^{2}$ and glucose concentrations $(\mathrm{mmol} / \mathrm{L})$ for the prediction of plasma nonesterified fatty acids (NEFA) ${ }^{2}$ concentration $(\mathrm{mmol} / \mathrm{L})$ in dairy goats

\begin{tabular}{lllll}
\hline Period $^{3}$ & $\mathrm{R}^{2}(\%)$ & Constant & BHB & Glucose \\
\hline $\mathrm{d}-24$ to -18 & $19.1^{* * *}$ & $0.05(-0.03$ to 0.14$)$ & $0.32(0.25 \text { to } 0.39)^{* * *}$ & $-0.09(-0.11 \text { to }-0.07)^{* * *}$ \\
$\mathrm{~d}-17$ to -11 & $36.4^{* * *}$ & $0.40(0.32 \text { to } 0.47)^{* * *}$ & $0.44(0.38 \text { to } 0.50)^{* * *}$ & $-0.15(-0.17 \text { to }-0.13)^{* * *}$ \\
$\mathrm{~d}-10$ to -4 & $35.4^{* * *}$ & $0.32(0.25 \text { to } 0.40)^{* * *}$ & $0.42(0.37 \text { to } 0.48)^{* * *}$ & $-0.14(-0.16 \text { to }-0.12)^{* * *}$ \\
$\mathrm{~d}-3$ to 3 & $40.4^{* * *}$ & $0.03(-0.02$ to 0.08$)$ & $0.60(0.55 \text { to } 0.66)^{* * *}$ & $-0.01(-0.02$ to 0.00$)$ \\
$\mathrm{d}$ 4 to 10 & $46.6^{* * *}$ & $0.50(0.43 \text { to } 0.57)^{* * *}$ & $0.53(0.48 \text { to } 0.59)^{* * *}$ & $-0.14(-0.17 \text { to }-0.12)^{* * *}$ \\
$\mathrm{~d} 11$ to 17 & $46.3^{* * *}$ & $0.70(0.62 \text { to } 0.78)^{* * *}$ & $0.50(0.44 \text { to } 0.55)^{* * *}$ & $-0.18(-0.21 \text { to }-0.16)^{* * *}$ \\
$\mathrm{~d} 18$ to 24 & $38.5^{* * *}$ & $0.67(0.58 \text { to } 0.75)^{* * *}$ & $0.48(0.41 \text { to } 0.54)^{* * *}$ & $-0.17(-0.20 \text { to }-0.14)^{* * *}$ \\
\hline
\end{tabular}

${ }^{1}$ Proportion of the variance in the dependent variable (i.e., NEFA) that was predictable from the independent variables in the model (i.e., BHB and glucose).

${ }^{2}$ Logged concentrations ( $\left.\mathrm{mmol} / \mathrm{L}\right)$.

${ }^{3}$ Days relative to delivery. The number of animals sampled in each period is presented in Table 1.

*** $P<0.001$. 
dairy cows, intensive metabolic adaptations are more pronounced in early lactation than in late pregnancy. However, in contrast to reports in dairy cows, we observed a relatively strong relationship between NEFA and BHB concentrations throughout the transition period and on days of peak concentrations of NEFA and BHB. Further research is needed to determine critical NEFA and BHB thresholds as predictors of disease and milk production loss in transition dairy goats.

\section{ACKNOWLEDGMENTS}

Fernanda Zamuner received a $\mathrm{PhD}$ scholarship financed by the Australian Government Research Training Program (Melbourne, VIC, Australia). The authors gratefully acknowledge Meredith Dairy Ltd. (Meredith, VIC, Australia) personnel for their assistance throughout this study. The authors declare there was no conflict of interest during the entire process of this study.

\section{REFERENCES}

Albay, M. K., M. Ç. Karakurum, Ş. Şahinduran, K. Sezer, R. Yıldız, and T. Büyükoğlu. 2014. Selected serum biochemical parameters and acute phase protein levels in a herd of Saanen goats showing signs of pregnancy toxaemia. Vet. Med. Czech 59:336-342. https:/ /doi.org/10.17221/7620-VETMED.

Baumgard, L. H., R. J. Collier, and D. E. Bauman. 2017. A 100-year review: Regulation of nutrient partitioning to support lactation. J. Dairy Sci. 100:10353-10366. https://doi.org/10.3168/jds.2017 $-13242$.

Bernard, L., P. G. Toral, and Y. Chilliard. 2017. Comparison of mammary lipid metabolism in dairy cows and goats fed diets supplemented with starch, plant oil, or fish oil. J. Dairy Sci. 100:93389351. https://doi.org/10.3168/jds.2017-12789.

Doré, V., J. Dubuc, A. Bélanger, and S. Buczinski. 2015. Definition of prepartum hyperketonemia in dairy goats. J. Dairy Sci. 98:45354543. https://doi.org/10.3168/jds.2014-9172.

Fougère, H., C. Delavaud, and L. Bernard. 2018. Diets supplemented with starch and corn oil, marine algae, or hydrogenated palm oil differentially modulate milk fat secretion and composition in cows and goats: A comparative study. J. Dairy Sci. 101:8429-8445. https://doi.org/10.3168/jds.2018-14483.

Grummer, R. R. 1995. Impact of changes in organic nutrient metabolism on feeding the transition dairy cow. J. Anim. Sci. 73:28202833. https://doi.org/10.2527/1995.7392820x.

Harmeyer, J., and C. Schlumbohm. 2006. Pregnancy impairs ketone body disposal in late gestating ewes: Implications for onset of pregnancy toxaemia. Res. Vet. Sci. 81:254-264. https://doi.org/10 .1016/j.rvsc.2005.10.010.

Johnson, M. M., and J. P. Peters. 1993. Technical note: An improved method to quantify nonesterified fatty acids in bovine plasma. J. Anim. Sci. 71:753-756. https://doi.org/10.2527/1993.713753x.

Karagiannis, I., N. Panousis, E. Kiossis, I. Tsakmakidis, S. Lafi, G. Arsenos, C. Boscos, and C. Brozos. 2014. Associations of pre-lambing body condition score and serum $\beta$-hydroxybutyric acid and non-esterified fatty acids concentrations with periparturient health of Chios dairy ewes. Small Rumin. Res. 120:164-173. https://doi .org/10.1016/j.smallrumres.2014.05.001.

LeBlanc, S. 2010. Monitoring metabolic health of dairy cattle in the transition period. J. Reprod. Dev. 56(Suppl.):S29-S35. https://doi .org/10.1262/jrd.1056S29.
Magistrelli, D., and F. Rosi. 2014. Trend analysis of plasma insulin level around parturition in relation to parity in Saanen goats. J. Anim. Sci. 92:2440-2446. https://doi.org/10.2527/jas.2013-6993.

Marutsova, V., and R. Binev. 2017. Body condition score, nonesterified fatty acids and beta-hydroxybutyrate concentrations in goats with subclinical ketosis. Agric. Sci. Technol. 9:282-285. https://doi .org/10.15547/ast.2017.04.053.

McArt, J. A. A., D. V. Nydam, and G. R. Oetzel. 2012. Epidemiology of subclinical ketosis in early lactation dairy cattle. J. Dairy Sci. 95:5056-5066. https://doi.org/10.3168/jds.2012-5443.

McArt, J. A., D. V. Nydam, G. R. Oetzel, T. R. Overton, and P. A. Ospina. 2013. Elevated non-esterified fatty acids and $\beta$-hydroxybutyrate and their association with transition dairy cow performance. Vet. J. 198:560-570. https://doi.org/10.1016/j.tvjl .2013.08.011.

McCarthy, M. M., S. Mann, D. V. Nydam, T. R. Overton, and J. A. A. McArt. 2015. Concentrations of nonesterified fatty acids and $\beta$-hydroxybutyrate in dairy cows are not well correlated during the transition period. J. Dairy Sci. 98:6284-6290. https://doi.org/10 $.3168 /$ jds.2015-9446.

Ospina, P. A., D. V. Nydam, T. Stokol, and T. R. Overton. 2010. Evaluation of nonesterified fatty acids and $\beta$-hydroxybutyrate in transition dairy cattle in the northeastern United States: Critical thresholds for prediction of clinical diseases. J. Dairy Sci. 93:546554. https://doi.org/10.3168/jds.2009-2277.

Ospina, P. A., J. A. McArt, T. R. Overton, T. Stokol, and D. V. Nydam. 2013. Using nonesterified fatty acids and $\beta$-hydroxybutyrate concentrations during the transition period for herd-level monitoring of increased risk of disease and decreased reproductive and milking performance. Vet. Clin. North Am. Food Anim. Pract. 29:387-412. https://doi.org/10.1016/j.cvfa.2013.04.003.

Overton, T. R., J. A. A. McArt, and D. V. Nydam. 2017. A 100year review: Metabolic health indicators and management of dairy cattle. J. Dairy Sci. 100:10398-10417. https://doi.org/10.3168/jds .2017-13054.

Panousis, N., G. Valergakis, E. Kalaitzakis, N. Siachos, E. Kiosis, and G. Arsenos. 2018. Evaluation of a portable ketometer for on-site monitoring of blood $\beta$-hydroxybutyrate concentrations in dairy sheep and goats. Rev. Med. Vet. 169:197-202.

Pichler, M., A. Damberger, T. Arnholdt, I. Schwendenwein, J. Gasteiner, M. Drillich, and M. Iwersen. 2014. Evaluation of 2 electronic handheld devices for diagnosis of ketonemia and glycemia in dairy goats. J. Dairy Sci. 97:7538-7546. https://doi.org/10.3168/ jds.2014-8198.

Pilotto, A., G. Savoini, A. Baldi, G. Invernizzi, C. De Vecchi, G. Theodorou, P. Koutsouli, and I. Politis. 2016. Associations between blood fatty acids, $\beta$-hydroxybutyrate, and $\alpha$-tocopherol in the periparturient period in dairy cows: An observational study. J. Dairy Sci. 99:8121-8126. https://doi.org/10.3168/jds.2016-10938.

Radin, L., M. Šimpraga, S. Vince, A. Kostelić, and S. Milinković-Tur. 2015. Metabolic and oxidative status of Saanen goats of different parity during the peripartum period. J. Dairy Res. 82:426-433. https://doi.org/10.1017/S0022029915000552.

Reynolds, C. K., P. C. Aikman, B. Lupoli, D. J. Humphries, and D. E. Beever. 2003. Splanchnic metabolism of dairy cows during the transition from late gestation through early lactation. J. Dairy Sci. 86:1201-1217. https://doi.org/10.3168/jds.S0022-0302(03)73704 $-7$.

Rook, J. S. 2000. Pregnancy toxemia of ewes, does, and beef cows. Vet. Clin. North Am. Food Anim. Pract. 16:293-317. https://doi.org/ 10.1016/S0749-0720(15)30107-9.

Smith, M. C., and D. M. Sherman. 2009. Goat Medicine. 2nd ed. Wiley-Blackwell, Ames, IA.

Suthar, V. S., J. Canelas-Raposo, A. Deniz, and W. Heuwieser. 2013. Prevalence of subclinical ketosis and relationships with postpartum diseases in European dairy cows. J. Dairy Sci. 96:2925-2938. https://doi.org/10.3168/jds.2012-6035.

Vasava, P. R., R. G. Jani, H. V. Goswami, S. D. Rathwa, and F. B. Tandel. 2016. Studies on clinical signs and biochemical alteration 
in pregnancy toxemic goats. Vet. World 9:869-874. https://doi .org/10.14202/vetworld.2016.869-874.

Wankhade, P. R., A. Manimaran, A. Kumaresan, S. Jeyakumar, K. Ramesha, V. Sejian, D. Rajendran, and M. R. Varghese. 2017. Metabolic and immunological changes in transition dairy cows: A review. Vet. World 10:1367-1377. https://doi.org/10.14202/ vetworld.2017.1367-1377.

Yadav, S. N., D. N. Kalila, A. Phukan, G. Mahala, S. Tamuly, T. C. Dutta, A. Saleque, D. Barman, and P. Thakuria. 2015. Prevalence of sub-clinical ketosis in goats of Guwahati, Assam. J. Anim. Vet. Adv. 14:382-385.

Zamuner, F., K. DiGiacomo, A. Cameron, and B. Leury. 2020. Effects of month of kidding, parity number, and litter size on milk yield of commercial dairy goats in Australia. J. Dairy Sci. 103:954-964. https://doi.org/10.3168/jds.2019-17051.

\section{ORCIDS}

F. Zamuner ( ) https://orcid.org/0000-0002-9409-8779

K. DiGiacomo (ㄴ) https://orcid.org/0000-0002-6590-3513

B. J. Leury ๑ https://orcid.org/0000-0001-9173-2730 